\title{
Current Trends in the Treatment of Human Epidermal Growth Factor Receptor-2 Negative Breast Cancer
}

\author{
Palanisamy Sivanandy ${ }^{1, *}$, Suresh Shanmugam ${ }^{1}$, Rui Ying Lau ${ }^{2}$, Jonathan Yvong Syen \\ Chin $^{2}$, Xiao Xiang Lee ${ }^{2}$, Yun Yun Lau ${ }^{2}$, Wai Ching Lee ${ }^{2}$, Iqbal Danial Said ${ }^{2}$, Jing Ying Lee ${ }^{2}$ \\ and Karthikayini Krishnasamy ${ }^{3}$
}

${ }^{1}$ Department of Pharmacy Practice, School of Pharmacy, International Medical University, Kuala Lumpur, Malaysia

${ }^{2}$ School of Pharmacy, International Medical University, Kuala Lumpur, Malaysia

${ }^{3}$ Department of Nursing - Oncology Nursing, University of Malaya Medical Centre, Kuala Lumpur, Malaysia

\begin{abstract}
Breast cancer affect almost 1 in 8 women and it is highest in developed and developing countries. There are many drugs exist for the treatment of breast cancer, but still the incidence of mortality and morbidity are high among all cancer types in most countries. Even though the conventional therapies play a major role in the management of breast cancer, its complications are obvious and unavoidable. The newer targeted drug therapy came in place to reduce complications in some extent, but not fully. Hence, a review was aimed to analyse the efficacy and safety of newer anticancer drugs that approved for the treatment of breast cancer by US-FDA from 2017 to 2019. The Olaparib, Talazoparib, and Ribociclib are the newly approved drugs for the treatment of breast cancer during this review period. Among these new drugs, Olaparib and Talazoparib alone or in combination with other anticancer drugs considered as safe and efficacious. Patients with Olaparib or Talazoparib as monotherapy have median progression-free survival of 2.8 to 8.6 months longer and has $42-46 \%$ lower risk of death $(P<0.001)$. A combination of conventional therapies and nonpharmacological approach are warranted for the best benefit of cancer patients and to improve their quality of life.
\end{abstract}

Keywords: Metastasis, olaparib, patient, talazoparib, therapy.

\section{INTRODUCTION}

Incidence of breast cancer is the highest among other malignancies that occur in women and breast cancer affects 1 in 8 women throughout their lives [1]. It can be classified into in situ and invasive breast cancer, where each is further subdivided into either ductal or lobular types [2]. In 2018, there were approximately 2 million people worldwide newly diagnosed with breast cancer. Out of 9 million deaths due to cancers, breast cancer contributed approximately $6.6 \%$. The age-standardised incidence rate for breast cancer among women in South-Eastern Asia is $38.1 \%$ [3-5]. In Malaysia, breast cancer ranked among the highest of all cancer types, contributing $17.3 \%$ of new cancer cases for both sexes in 2018 . There were approximately $7593(32.7 \%)$ breast cancer incidences out of 23218 new cancer cases for female group reported. The mortality rate of breast cancer is $11.82 \%$, which is the second highest cancer deaths after lung cancer [4].

This review was aimed to provide an overall knowledge on breast cancer and to analyse the

*Address correspondence to this author at the Department of Pharmacy Practice, School of Pharmacy, International Medical University, 57000 Kuala Lumpur, Malaysia; Tel: +601112327819; E-mail: sivapalanisamy@yahoo.co.in

ISSN: 2223-3806 / E-ISSN: 1927-5951/20 efficacy and safety of newer anticancer drugs that approved for the treatment of human epidermal growth factor receptor 2 (HER2)-negative breast cancer by US-FDA from April 2015 to March 2019. The main source of data used is PubMed. Articles on HER2positive breast cancer and animal studies were excluded. According to Centre Watch, there are altogether 3 drugs reviewed and 09 articles were collected. All the authors independently extracted the relevant information from the studies that fulfilled our inclusion criteria and any disagreements were resolved with consensus. The information extracted included the trial phase, region, conditions of subjects (cancer stage, comorbid conditions, median progression-free survival rate (PFS), objective response rate (ORR), hazard ratio) and the outcome measures. This information was gathered and summarized into paragraphs, introducing each anticancer drug comprehensively.

\section{CLASSIFICATION OF BREAST CANCER}

Breast cancers are classified according to their molecular and histology subtypes.

\subsection{Molecular Classification}

Invasive breast cancer can be categorised into varies molecular subtypes depending on the mRNA

(C) 2020 SET Publisher 


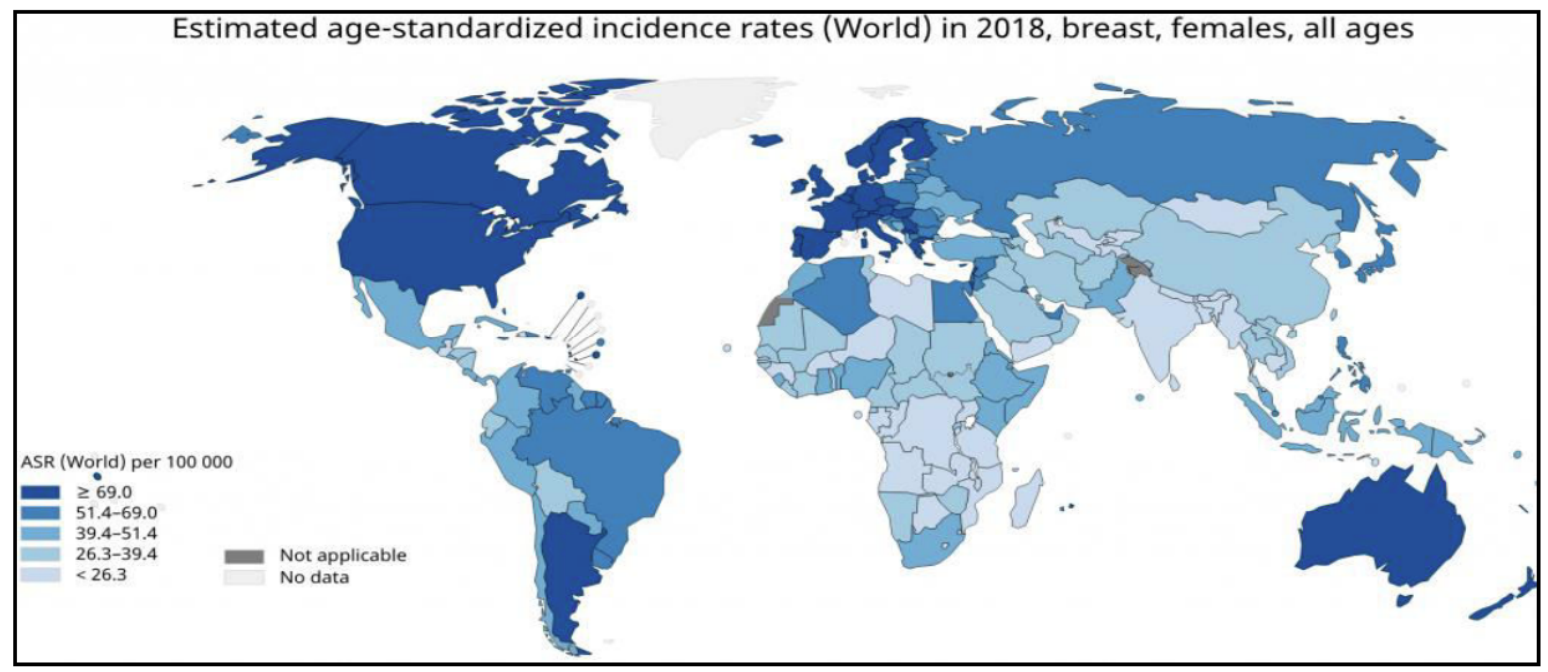

Figure 1: Report of breast cancers from different parts of the world [5,6].

Source: Globocan, Worldwide reported breast cancer 2008, 2012, and 2018 International Agency for Research on Cancer (IARC).

Table 1: Classification of Breast Cancer Based on Molecular Subtypes

\begin{tabular}{|c|c|}
\hline Molecular subtypes & \multicolumn{1}{c|}{ Description } \\
\hline \hline Luminal A & $\begin{array}{c}\text { Luminal A type is characterized as oestrogen-receptor (ER) and/or progesterone-receptor (PR) positive, } \\
\text { HER2 negative and has little Ki-67 protein, which controls cell proliferation rate. Luminal A cancers are } \\
\text { generally low-grade and show favourable prognosis [7-9]. }\end{array}$ \\
\hline Luminal B & $\begin{array}{c}\text { Luminal B type is ER and/or PR positive, consists large amount of Ki-67 protein and either HER2 negative } \\
\text { or positive. Luminal B type of cancers have poorer tumour grade and less favourable prognosis compared } \\
\text { with luminal A [7-9]. }\end{array}$ \\
\hline HER2 & $\begin{array}{c}\text { HER2 type tends to be ER and/or PR negative, while HER2 appears to be positive. Those cancer cells } \\
\text { have a higher proliferation rate compared to luminal type and have a poor prognosis [7-9]. }\end{array}$ \\
\hline Basal/Triple negative & $\begin{array}{c}\text { Basal/triple negative type is ER, PR and HER2 negative. BRCA1-related mutations are mostly both triple } \\
\text { negative and basal-like. These tumors are more commonly seen among younger women, and also } \\
\text { among African-American or Black or non-Hispanic Black women [7-9]. }\end{array}$ \\
\hline Normal & \begin{tabular}{c} 
Normal type is similar to luminal A type, but its prognosis is slightly poorer than luminal A type [9,10]. \\
\hline
\end{tabular} \\
\hline
\end{tabular}

expression profiles. There are a total of 5 subtypes, which are Luminal $A$, luminal $B$, human epidermal growth factor receptor 2 (HER2), basal/triple negative and normal type [7-10]. Table 1 displays the details of each subtype.

\subsection{Histology Classification}

In-situ breast carcinoma is sub-classified into 2 categories, lobular cancer in situ (LCIS) and ductal carcinoma in situ (DCIS). DCIS lesions mostly appear in the mammary ducts while LCIS may originate from the unusual development of cells, which is known as atypical lobular hyperplasia [7]. DCIS can develop into invasive carcinoma and it contributes to $30 \%$ of all malignant lesions. Conversely, LCIS is usually polycentric and bilateral [11]. Invasive breast carcinoma has different subtypes. The most common subtypes are the infiltrating ductal (approximately 70$80 \%$ ) and infiltrating lobular (approximately 5-10\%). Inflammatory, metaplastic, Tubular, Mucinous, Medullary, Papillary, Paget disease and infiltrating, Squamous cell, Adenoid cystic, and Secretory cancer are examples of other less common subtypes [11].

\section{ETIOLOGY}

There are different causes of breast cancer, such as past medical history of breast cancer, genetic predisposition, hormone and reproductive factors, 
family history associated with cancer, and other risk factors. The causes are discussed in detail as below:

\subsection{Past Medical History of Breast Cancer}

Based on the outcome obtained by Hartmann et al., there is higher probability of developing cancer in another breast of a women who has previous history of breast cancer. Among 616 unilateral breast carcinoma, $55.5 \%$ occurred in the same breast whereas $44.5 \%$ were found to be in the contralateral breast. Based on the follow-up conducted in the first 5 years of the study, there was a greater incidence of ipsilateral breast cancer compared to that of contralateral cancer (Relative risk: $1.88 ; 95 \% \mathrm{Cl}$ : 1.33-2.64) [12].

\subsection{Significant Family History}

Women with strong family history of breast carcinoma have greater relative risk (RR) (RR:1.93; $95 \% \mathrm{Cl}: 1.58-2.32$ ), compared to those with poor family history (RR: 1.43; 95\% Cl: $1.15-1.75$ ) and subjects without a family history (RR: $1.18 ; 95 \% \mathrm{Cl}$ : 1.01-1.37). Hence, if there is strong family history, the patient may associate with a greater probability of getting breast cancer [12]. There is a correlation between maternal or paternal relatives, which lead to the likelihood of developing breast cancer. If the close relative develops breast cancer of both breasts at the early stage of life, the likelihood of getting breast cancer is the greatest [13]. Hence, first-degree relatives are the most crucial in predicting the risk, however, second-degree relatives may also alleviate the risk.

\subsection{Genetic Causes}

Mutation of genes involving BReast CAncer gene 1 (BRCA1) and BRCA2 primarily contributes to inherited breast cancer. For carriers of mutated BRCA1 genes, their lifetime breast cancer risk is between $65 \%-81 \%$, whereas for BRCA2 carriers the risk ranges between $45 \%-85 \%$ [14-16].

\subsection{Reproductive Factors and Endogenous Hormone Exposure}

The level of endogenous oestrogen throughout a woman's lifespan have growth or protective effects against breast carcinoma. Both pre and postmenopausal women with early menarche has higher risk for breast carcinoma. It is statistically shown that a delay in the first cycle of menstruation by 2 years is linked to a reduction of percentage of approximately $10 \%$ in the likelihood of developing breast carcinoma [17]. Pregnancy and the age giving first birth are also responsible in breast carcinoma progression. In general, nulliparous women are often associated with elevated likelihood of getting breast cancer in comparison with parous women. Women who give birth at young age will provide protective effect against breast carcinoma. However, those who give first birth at advanced age present with a higher likelihood of developing breast carcinoma when compared with nulliparous women [18].

Testosterone, the high level of this endogenous sex hormone levels predisposes both pre and postmenopausal women at a higher chance of developing breast carcinoma [RR 2.86-3.28] [19]. Elevation of breast cancer risk has been related with later menopause onset. There is also been reported of an increased possibility in developing breast carcinoma by $3 \%$ for each year delay in menopause onset; whereas the possibility increased to $17 \%$ for every 5 -year delay [20].

\subsection{Exogenous Hormone Exposure}

Studies showed that there is a correlation between hormone replacement therapy (HRT) and the likelihood of developing breast carcinoma. In a randomized control trial, there is notable increased breast cancer risk, delayed diagnosis of breast cancer and increased mortality rate for postmenopausal women with intact uterus who used a combination of oestrogen and progestin. However, for postmenopausal women without a uterus, consuming unopposed oestrogen did not affect their breast carcinoma diagnosis and markedly reduced breast carcinoma likelihood [21]. Meanwhile, it is also suggested that postmenopausal women with unopposed oestrogen are correlated with a greater cumulative risk of breast carcinoma development by $23 \%$ at the age of 70 [22]. Breast carcinoma risk is correlated with both the timing and duration of initiating HRT. There is a higher likelihood of having breast carcinoma detected in women who initiated HRT at early stage of menopause. Furthermore, the use of combined HRT in long term (greater than 5 years) will statistically raise the possibility of breast carcinoma, but in short-term use, it does not significantly increase the risk [23].

\subsection{Risk Factor and Risk Prediction}

Risk factors such as age, breast pathology, lifestyle and dietary causes and environmental factors are correlated with a higher probability of breast carcinoma progression. 


\subsubsection{Age}

Age is one of the predictors in developing breast cancer. Based on statistics, woman in the United States possesses a lifetime risk of 1 in 8 woman of developing breast cancer. Based on the age group of birth to 39 years, $40-59$ years and 60-69 years, the chances of developing breast cancer are 1 in 202, 1 in 26 and 1 in 28 respectively [12].

\subsubsection{Breast Pathology}

The RR for breast cancer linked with atypia was found to be $4.24(95 \% \mathrm{Cl}, 3.26$ to 5.41$)$, in comparison with a RR value of $1.88(95 \% \mathrm{Cl}, 1.66$ to 2.12$)$ for proliferative growth in the absence of atypia and RR of $1.27(95 \% \mathrm{Cl}, 1.15$ to 1.41$)$ for non-proliferative growth [24]. Thus, women with atypia in comparison to those without atypia, have a greater chance of developing breast cancer.

\subsubsection{Lifestyle and Dietary Cause}

Risk factors been identified of the pathogenesis of breast cancers; linked to nutrition, sedentary lifestyle (obesity, alcohol consumption, dietary intake) in postmenopausal women [25]. The recent a multi-centre prospective cohort study from European Prospective Investigation into Cancer and Nutrition (EPIC), demonstrated the RR appeared to be 1.28 for both overweight and obese women when compared to normal weight women [24]. There are number of epidemiological studies shown alcohol consumption is also associated to increased risk of breast carcinoma and mortality. The possibility is found to be proportional to the amount of alcohol consumed. Alcohol level as little as 5.0 to $9.9 \mathrm{~g}$ daily, or 3 to 6 drinks weekly $(R R=1.15 ; 95 \% \mathrm{Cl}: 1.06-1.24)$ is statistically significant in elevating breast carcinoma risk [26]. Even though the mechanism of carcinogenesis induced by alcohol are still unclear, but regular intakes of some amount of alcohol may affect sex hormones levels for pre and post-menopausal women.

\subsubsection{Environmental Cause}

Studies suggest that environmental exposures such as chemicals, diet, radiations and other factors, during maturity of breast tissue, may increase risk of breast cancer later in life. National Institute of Environmental Health Sciences (NIEHS), has conducted studies to identify environmental exposures that can increase risk of breast cancer, using animal to understand the role of environmental agents in the initiation as well as progression of cancer. Some example of exposure was identified are such as female airline flight attendants whom were exposed to higher cosmic radiation while flying had higher incidence rate of breast cancer [27]. Another example can be seen following a nuclear accident took place in Chernobyl where there is a notable 2-fold increase in breast cancer among women who were exposed to the radiation [28].

\section{PATHOPHYSIOLOGY}

\subsection{Hormone Signaling Pathway}

Oestrogen or oestrogen, together with other hormones, in the development of female sex hormone and secondary sex characteristics, has an essential role in the regulation of the menstrual cycle and reproduction. Therefore, oestrogen has been acts as a mammary epithelial cell carcinogen; exposing reproductive risk for breast cancer mediated by hormonal mechanisms. The proliferative effects of oestrogen are mediated by an intracellular receptor, the oestrogen receptor (ER) [29-31]. The two known variants of ER receptor are ERa and ER $\beta$. The ERa primarily expressed in mammary gland development whereas ER $\beta$ involved more in lobulo-alveolar development $[29,30]$. When oestrogen passes through the cell membrane, it binds to the ER, forming an active transforming factor that binds DNA as a dimer at specific oestrogen response elements (ERE) and ultimately leading to its transcriptional activation $[29,30,32]$. Gene transcription can be furthered modified by interactions between the ER and coactivators or corepressors at the nuclear level, thus permitting tremendous variability in the natural oestrogen $17 \beta$-estradiol (E2) actions at gene level [30]. The exact molecular mechanism by which $E 2$ affects the development of breast cancer has not yet been fully understood. Extensive experimental evidences support that E2 is able to stimulate cell proliferation through ERa and initiate mutation due to errors that occurred during DNA replication $[33,34]$. Under continued influence of E2, cells with acquired mutations are further expanded until sufficient for oncogenic transformation to take place $[30,33,34]$. In addition, Wei Yue et al. had demonstrated that E2 can also affect breast carcinoma formation independent of ER functionality via its metabolites. During metabolism, estrogens undergo hydroxylation at 2-, 4- and 16apositions. 2-OH-E2 and 4-OH-E2 can cause DNA damage via oxygen free radicals generated by redox cycling [34]

\subsection{Growth Factor Signaling Pathway}

The epidermal growth factor (EGF) family of ligands and receptors has received experimental support for 
their pathological overexpression and functional relevance for breast cancer in vitro, in vivo and ongoing clinical trials. The insulin-like growth factor 1 (IGF-1) mainly regulates the biology of mammary gland and an elevation of serum IGF-1 levels are linked with a higher risk of breast cancers. The human epidermal growth factor family receptors (HER) are much more directly implicated in the pathophysiology of breast cancer. In pre-invasive and invasive breast cancers, the overexpression of the HER2 protein and amplification of the ERBB2 gene are commonly found [35]. The HER family receptors can activate several downstream signaling pathways which includes classic signal transduction of mitogen activated protein kinase (MAPK) / extracellular signaling regulating kinase (ERK) and phosphatidylinositol-3 kinase (PI-3K)/AKT pathways which promote cell proliferation and simultaneously inhibit apoptosis [35-37]. The protooncogene AKT1 and tumor suppressor gene PTEN are also mutationally or epigenetically altered in breast cancers, activating those important signaling pathway [35]. Moreover, growth factors exert their main effects on the cell cycle and cell survival by regulating cyclin D1 and $\mathrm{Bcl}-2 / \mathrm{BcIXL}$ respectively [37]. Overexpression of cyclin D1 may directly or indirectly result in maturation of tumour cells [38].

\subsection{DNA Repair Pathways}

Human cells are continuously exposed to variety of stressors such as reactive oxygen species and ionizing radiations, inducing repairable and unrepairable DNA damage. Therefore, the damages lead to several pathways to eliminate DNA lesions and maintain genome stability and integrity; underlying cause for the development of variety of cancers, and breast cancer is no exception. Tumour suppressor genes are primarily involved in maintaining the DNA integrity. Therefore, it is involved in the progression of breast cancer at the familial level by germline transmission of mutated alleles as well as in the development of sporadic breast cancer through the somatic mutation at the tissue level. The BRCA1 and BRCA2 genes are accounted for most of familial breast cancers [35]. Nonetheless, BRCA1 mutation or any abnormalities in other proteins that interact with BRCA1 to carry out DNA repair functions involving double strands breaks may be observed occasionally in some cases of breast cancer. Another classic tumour-suppressor gene p53 (TP53) is also frequently mutated in breast cancer. The loss-offunction mutation in TP53 in one allele carries a 25fold increased risk of developing malignancy includes breast cancer at early age, defining a very rare familial clustering of cancers known as Li-Fraumeni syndrome [35]. The Li-Fraumeni syndrome (LFS), is also known as sarcoma family syndrome of $\mathrm{Li}$ and Fraumeni, 'Sarcoma, breast, leukemia, and adrenal gland (SBLA) syndrome', and SBLA syndrome. Characterization of cancer-causing genes and other genetic factors is of great important to identify cancer-prone individuals and contributes to the understanding of sporadic cancers.

\section{CLINICAL MANIFESTATIONS}

Symptoms of breast cancer are often noticed first, when the patient self-examine the breast tissue or the skin around the breast. The classical manifestation of breast tumour is the detection of a mass or a lump within the breast tissue or the underarm, which may or may not be painful [39-41]. Other clinical manifestations are nipple retraction or nipple discharge, breast asymmetry, including swelling or thickening of whole or part of the breast, breast size or breast shape changes may also be one of the symptoms of breast cancer in case of nonpalpable lumps [9,39,41-43]. Other possible symptoms of breast cancer include skin changes around the breast area such as scaly or flaky skin, skin redness, warmth, irritation or dimpling [9,11,41-43]. In case of metastatic breast cancer, symptoms such as weight loss, jaundice and fatigue may also be present [2]. Symptoms of breast cancer may vary between individuals, some with easily identified breast or skin changes whereas some having no detectable symptoms at all. Some of the symptoms may also manifest due to normal physiological changes such as menstruation or hormonal changes $[42,43]$. Hence, any breast changes or symptoms detected should be reported to the physician and further examination with mammograms, ultrasound or other methods will be required to determine the precise location and extent of the tumour [40].

\section{DIAGNOSIS OF BREAST CANCER AND PATHOLOGY}

Physical examination is the primary test should be done to inspect any abnormality of tissues or skin changes around the breast area. Patient can either perform breast self-exam or consult a physician for clinical breast exams. The procedures are done by positioning patients sitting upright or in supine position to inspect any breast size changes, nipple retraction, skin changes, dimpling or peau d' orange (orange peel skin) $[23,44]$. Palpation and examining part of the breast tissue and underarm is important to detect any lump or hard mass, usually found solitarily and unilaterally $[44,45]$. Nipple discharge is also can be 
detected by gently squeezing the nipple [44]. Radiological imaging is a pivotal in the screening and diagnosis of breast cancer. Mammography is a specialised $\mathrm{x}$-ray screening optimised for breast cancer detection, capable of producing high resolution images of the breast [45]. Mammography is the most widely used imaging test and remains the mainstay to identify breast cancer, with more than $90 \%$ of the tumours identified through mammography $[23,44]$. Screening mammography can help in identifying and staging breast tumours to allow more appropriate conservative local therapy [46]. According to a review by American Cancer Society (ACS), a $30 \%$ reduction in breast cancer mortality rate was noticed among women 50 years old or above that had undergone mammography screening. Diagnostic mammography such as mammography film digitisation, positron emission tomography (PET), magnetic resonance imaging (MRI), or computed tomography (CT) scanning are more sensitive but less specific and does not offer much higher reduction in mortality [46]. Hence, advanced diagnostic test is not recommended for routine screening of breast tumours in women with standard risk. However, more sensitive screening techniques are recommended in women with genetic risk, such as BRCA1 or BRCA2 carriers, with breast implants or with strong family history of breast cancer as the incidence of cancer is higher within these subgroup of patients $[2,46]$.

Ultrasonography is also used for breast imaging purposes, which is indicated in women aged 30 years or below with palpable lump in the breast $[11,46]$. Ultrasonography is very effective in differentiating between cystic and solid lumps, however it is less effective for the detection of lumps deep into the tissues [45]. Tomosynthesis, also known as 3-D mammography, is a new yet promising diagnostic technique for breast cancer, capturing multiple layers of breast in a single process $[41,45]$. This technique may improve the sensitivity of mammogram and it is currently under evaluation for its performance in improving patient's prognosis [45]. Apart from imaging facilities, breast cancer also can be diagnosed by tissue sampling through fine needle biopsy, core needle biopsy and excisional biopsy. It is the only definitive diagnostic procedure in identifying the presence of breast cancer through histologic analysis [21]. For the identification of solid lumps, fine-needle aspiration (FNA) or core biopsy can be used to extract tissue samples for cytology [39,44]. As for non-palpable lump, collection of tissue sample using FNA requires stereotactic or ultrasound guidance. Excisional biopsy is done only if needle biopsy fails to show conclusive results $[41,44]$.

\section{MANAGEMENT}

Even though, only few drugs (Olaparib, Talazoparib, and Ribociclib) were approved by the US-FDA during the search period of April 2015 to March 2019 for the treatment of HER2-negative breast cancer, it is essential to discuss the available conventional drugs for the treatment of breast cancer. Hence, the following sections will briefly discuss all the drugs that are available for the treatment of HER2-negative breast cancer.

The paradigm of treating breast cancer has changed evolutionally over the last decades; targeted therapies have improved patient outcomes tremendously. Conventional treatments such as surgery, radiotherapy and systemic therapy has emerged into new era, comparing where surgery alone can tackle the tumour. The main challenge faced particularly in treating metastatic breast cancer, despite advanced systemic therapies, the disease remains incurable. Even though multiple targeted drugs are being introduced, the tumour becoming aggressive invades these agents especially when there is lack in biologic process. Metastatic cancer requires systemic therapy as the principal therapeutic modality includes chemotherapy, hormonal therapy, targeted therapy and immunotherapy [47]. Generally, the management of metastatic breast cancer is determined based on the extent and characteristics of the tumour [48].

Over the years, surgery modality has become less invasive techniques and advanced tremendously to provide cosmetic appearance in breast conservation and reconstruction for women requires mastectomy. Hence, surgeons remain as crucial members of the multi-disciplinary team in the mainstay treatment of breast cancer. The types of breast surgery based on the location, site, infiltration of tumour, which, depending on the situation, serve different purposes in treating the cancer. For instance, surgical intervention is possible to fully remove cancer cells or to relieve the symptoms of an advanced cancer. There are two types of surgery that can be done to treat breast cancer. Breast-conserving surgery, where only a small portion of the breast that contains cancer is removed and mastectomy, removal of the whole breast including the breast tissues $[48,49]$. Although advanced breast cancer that has metastasised is unlikely to be treated through surgery, it can still be useful in treating the symptoms and slowing down the spread of the cancer 
[49]. Radiotherapy, another treatment modality for breast cancer and plays a vital role in maximising local disease control by enabling breast conservation and increase better survival. The therapy is a highly targeted and effective way in destroying undetectable and reducing chances of recurrence of cancer cells by using high energy rays after surgery. Radiotherapy is usually started three to four weeks after a surgery and is usually done at a radiation centre [50].

\subsection{Pharmacological Management}

There are different groups of drugs used in the treatment of breast cancer, including antimetabolites, microtubules inhibitors, topoisomerase inhibitors, alkylating agents, hormone therapy and targeted drug therapy. These drugs are further discussed below in detail.

\subsubsection{Antimetabolites}

The antimetabolites are a group of anticancer agents, having similar structure with purines or pyrimidines within the cell but differs enough to interfere with their metabolism [51]. Antimetabolites will be converted into analogue of cellular nucleotides by enzyme pathway in the cells, which inhibit the enzymes that are essential for nucleic acid synthesis. As nucleic acid synthesis is affected, the growth of breast cancer cells is inhibited [52]. There are three types of antimetabolites anticancer agents, which are folic acid antagonist, pyrimidine antagonist and purine antagonist. In normal cells, folic acid is essential for deoxyribonucleic acid (DNA) formation. It will be reduced to tetrahydrofolate in the presence of dihydrofolate reductase enzyme, in order to be active for purine and thymidylate synthesis. Methotrexate is the folic acid antagonist used in breast cancer chemotherapy [53]. It acts as a competitive inhibitor of folate with three mechanism of actions, which are to inhibit dihydrofolate reductase, inhibit thymidylate and alter the transport of tetrahydrofolate [53,54]. Therefore, the formation of DNA, ribonucleic acid (RNA) and proteins are inhibited [53]. As actively proliferating tissues are more sensitive toward methotrexate in S-phase of cell cycle, it may impair the malignant growth of cancer tissues without causing damage to normal tissues [53,55]. 5-fluorouracil (5-FU), capecitabine and gemcitabine are the examples of anticancer agents under pyrimidine antagonists' analogue. They are nucleoside inhibitors whereby their metabolites will be incorporated into RNA and DNA. The alteration in RNA translation and DNA transcription will then induce cancer cell deaths [56]. There is no anticancer agent under purine antagonist class, however, that can be used to treat breast cancer.

\subsubsection{Microtubules Inhibitor}

Microtubules inhibitor are class of drugs inhibit the function of cellular microtubules which are key elements of the cell cytoskeleton composed of polymers of tubulin. These microtubules are engaged in cellular processes and it has critical role in mitosis that makes them targets for cancer therapy. It can be classified into two types, which are microtubules stabilizers and microtubules destabilizers. Microtubules stabilizers will induce microtubule polymerization to promote nucleation and elongation under polymerization phase reaction. This will lead to overpolymerization of inappropriately stable, non-functional microtubules at which depolarization is inhibited. Inhibiting depolarization will cause inhibition of cell division and lead to tumour cell death. Paclitaxel, Docetaxel and Ixabepilone are the examples of taxane plant alkaloids with microtubules stabilizers activity for treating breast cancer [57].

In contrast, microtubules destabilizers will inhibit polymerization by binding to tubulin directly with high affinity. It will bind to the $\beta$-subunit near the guanosine triphosphate (GTP)-binding site on tubulin. This binding alters the conformation of the tubule dimers and inhibits guanosine diphosphate (GDP)-GTP exchange. This will lead to inhibitions of assembly of microtubules and interferes with spindle fibers formation. The cells will be arrested at prometaphase and thus induce apoptosis of cancer cells. The examples of microtubules destabilizers for breast cancer chemotherapy are Vinblastine sulfate, Vincristine sulfate, Vindesine sulfate and Vinorelbine [57].

\subsubsection{Topoisomerase Inhibitors}

Human DNA topoisomerase enzyme has various important roles for the human cells especially in the aspect of DNA manipulation. This includes the replication and transcription of DNA as well as catenating and disentangling of linear and circular DNA $[58,59]$. These broad roles of topoisomerase in maintaining DNA topology allow it to become a suitable target for a wide range of cancer chemotherapeutic agents. In the management of cancer, inhibition of topoisomerase enzyme is a crucial mechanism. The anthracycline agent is the first-class topoisomerase inhibitor used as chemotherapeutic agents in treating cancer $[58,60]$. Clinically marketed anthracycline derivatives that are widely used in breast cancer treatment includes Epirubicin and Doxorubicin. These 
anthracycline agents predominantly affect type Ila topoisomerases which fits itself into a cleaved and bound DNA, forming topoisomerase complex and prevents the re-ligation of DNA. The formation of "cleavage complex" subsequently prevents the turnover of the enzyme and increases the cytotoxic cleavage complex level in the cancer cells [60]. Furthermore, anthracyclines are also known to induce cell death by producing free radical species [58,60,61]. However, this mechanism also caused the agent to be responsible in certain additional toxicity such as cardiotoxicity. Apoptosis of the cardiac muscle cells can occur as the production of hydrogen peroxide and superoxide anions induce oxidative stress in the cells [61]. Hence, this can further lead to acute and chronic cardiac complications.

\subsubsection{Alkylating Agents}

Alkylating agents are cell-cycle nonspecific antineoplastic drugs [62]. They interact with DNA, RNA and proteins through alkylation by forming covalent bonds that will impair the functionality of cells. Among all targets, binding to DNA irreversibly is the most crucial cytotoxic reaction to tumour cell as it interrupts the cell replication and DNA synthesis [47]. These agents will form a highly reactive intermediates, carbonium ion which is an electrophile that interacts with the nucleophilic sites on target DNA molecules [62]. Nitrogen mustards are a class of alkylating agents that forms $\mathrm{N}$-alkylaziridinium ions [58]. They induce DNA adducts formation, exert anti-replicative effects and apoptosis [63,64]. Examples of compounds under this class include Cyclophosphamide, Ifosfamide, Melphalan, Mechlorethamine, Chlorambucil, Estramustine and Bendamustine. Other categories of alkylating agents include alkyl sulfonates (Busulfan and Treosulfan), nitrosoureas (Lomustine, Carmustine and Streptozocin), ethylenimines (Thiotepa and Altretamine), triazines (Dacarbazine), tetrazines (Temozolomide) $[62,64,65]$. Cisplatin, Carboplatin and Oxaliplatin belong to platinum agent category of alkylating agents and have been approved for the use in treating advanced breast cancer $[47,66]$. They act as a DNA crosslinking agent within the intra- and interstrand DNA, and the adducts of DNA-platinum impede the transcription and replication of DNA $[66,67]$. However, dose dependent bone marrow toxicity and gastrointestinal toxicity are the major toxic effects of most alkylating agents [62].

\subsubsection{Hormone or Endocrine Therapy}

Hormone or endocrine therapy is crucial when breast cancer patients show positive for either oestrogen receptor-positive, progesterone receptorpositive or both [68-71]. Estrogen and progesterone are hormones bind to specific receptor found in breast cancer cells, further stimulating the growth of neoplastic cells [69]. There are several mechanisms that have been proposed such as impeding the function of ovary, blocking the formation of oestrogen and preventing the action of oestrogen on breast cancer cells $[48,70,71]$. Oophorectomy (ovariectomy) or luteinizing hormone-releasing hormone (LH-RH) analogues work by inhibiting the ovarian function $[48,70,71]$. Examples of $\mathrm{LH}-\mathrm{RH}$ agonist approved by FDA are goserelin, leuprolide and triptorelin [70]. Aromatase inhibitor (Al) blocks the enzyme aromatase and eventually prohibits the production of oestrogen. $\mathrm{Al}$ are highly effective in postmenopausal women with advanced breast cancer as aromatase enzyme plays a vital role in oestrogen production and also has demonstrated efficacy in the treatment $[48,71]$. Currently, the drugs that are available under this category are anastrozole, letrozole and exemestane $[48,70,71]$. Selective oestrogen receptor modulator (SERM) as with selective oestrogen receptor degrader (SERD) interrupt the ability of oestrogen to function upon tumour cells [48]. SERM acts as oestrogen agonist, oestrogen antagonist or both while SERD only serves as oestrogen antagonist. Tamoxifen, raloxifene and toremifene are example of SERM drugs that are approved by FDA. The common side effects for these medications are hot flashes, mood changes and vaginal dryness [50]. Fulvestrant is the only SERD drug approved by FDA which is indicated only if other hormonal drugs are not effective anymore [48]. Among the drugs, tamoxifen is the only active adjuvant or additional endocrine therapy in pre- and postmenopausal patients [72].

\subsubsection{Targeted Drug Therapy}

The greater understanding of cell signaling systems and progress of research in molecular biology, has emerged array of potential targets of therapy for breast cancer which is directed to specific differential growth processes; in addition to conventional chemotherapy. Moreover, these therapy uses pharmacological agents to inhibit growth, increase cell death and restrict the spread of cancer. This therapy mostly does not harm normal cells and exhibits less severe side effects when compared to chemotherapy [50]. Targeted therapy works mainly by blocking specific protein or enzyme that are accountable for the proliferation of cancer cells. For instance, trastuzumab, a monoclonal antibody that is widely used to treat breast cancer works by binding itself to the extracellular domain IV of 
human epidermal growth factor receptor 2 (HER2) [73]. Trastuzumab will bind to the receptors and inhibit the intracellular signal that involves in the growth, antiapoptosis, proliferation, as well as angiogenesis of cancer cells [74]. Other than that, lapatinib is also commonly used as a targeted therapy in breast cancer. It inhibits the phosphorylation of the HER1 and HER2 tyrosine kinase receptors by specifically bind to them and thus blocking the proliferation pathway of the breast carcinoma [74]. Possible side effects of targeted therapy include weakness, diarrhoea, rashes, nausea, and vomiting but they are not as severe as chemotherapy. Moreover, these minor side effects normally will become less severe after the first treatment $[73,74]$.

\subsubsection{Newer Drugs in Breast Cancer Treatment}

During this review period, there were three drugs namely Olaparib, Talazoparib, and Ribociclib were approved for the treatment of HER2-negative breast cancer.

Olaparib is a new and the first drug approved by Food and Drug Administration (FDA) in year 2018 for germline BRCA-mutated, HER2-negative metastatic breast cancer treatment [75]. It is a poly (adenosine diphosphate-ribose) polymerase (PARP) inhibitor [75,76]. When DNA damage occurs, the PARP enzyme will be activated, and it helps to repair DNA through single-strand breaking and base excision repair [76]. Hence, in tumour cell, PARP enzyme plays a role in maintaining DNA integrity, error-repairing as well as its survival. Suppressing the enzyme will stall the replication forks and accumulate double-strand breaks which will be highly cytotoxic when not corrected. Since BRCA-mutated cells are not capable in performing homologous repair, the inhibition of PARP enzyme will lead to genomic instability and ultimately causes apoptosis of the cells [76, 77]. Therefore, olaparib acts as PARP inhibitor in promoting tumour cell deaths.

Talazoparib is also a PARP inhibitor for the treatment of breast cancer approved in year 2018 by FDA. Therefore, it is indicated specifically for patients with mutation of BRCA-germline (gBRCAm), HER2negative advanced breast cancer either locally advanced or metastatic [78]. In EMBRACA randomized phase 3 open trial, talazoparib shown to be significantly superior than standard chemotherapy (capecitabine, eribulin, gemcitabine, or vinorelbine) in terms of progression-free survival (PFS) for 3 months in advanced breast cancer patients and mutation in germline BRCA1/2, [79]. Some common side effects associated with Talazoparib are fatigue, nausea and anaemia [80].

Ribociclib with combination of aromatase inhibitor was approved by FDA in 2017 for treating metastatic breast cancer. In normal cell cycle, the passage of $\mathrm{G} 1$ checkpoint is through cyclin D- cyclin-dependent kinase (CDK) 4/6- p16- retinoblastoma (Rb) pathway. During mitosis, the level of cyclin $D$ increases and activates CDK 4/6. The activated CDK4/6 will cause phosphorylation in $\mathrm{Rb}$ protein which initially bounded with E2 Factor (E2F). The phosphorylation of $\mathrm{Rb}$ protein leads to bond breaking, releasing of free E2F which is necessary for transcription during cell proliferation. In cancer cells, cyclin D-CDK 4/6-p16- Rb pathway is often disrupted causing abnormal cell proliferation. To reduce cancer cell proliferation, ribociclib acts as selective CDK4 and CDK6 inhibitor to block cell cycle progression without inhibiting S-phase activity [81-83]. The combination of ribociclib with letrozole (nonsteroidal aromatase inhibitors) serves as the first line pharmacological treatment for HR+ and human epidermal growth factor receptor 2-negative (HER2-) advanced breast cancer.

When comparing the efficacy of all three new drugs that recently approved by US-FDA for the treatment of HER2-negative breast cancer, Olaparib has a potential to extend the median progression-free survival (PFS) of 2.8 months with $42 \%$ lower risk of death, but Talazoparib can extend the median PFS up to 8.6 months with $46 \%$ lower risk of death and the platinumfree regimen can extend between 4 months and 5.6 months PFS. However, the Ribociclib can extend the PFS up to 20.5 months when given in combination with fulvestrant.

All these drugs have similar safety profile in causing gastrointestinal side effects. However, except Olaparib, all other drugs have high potential to cause pancytopenia, alopecia to extensive level in addition to gastrointestinal, urinary tract and neurological complications. The outcome, safety and efficacy of the newer drugs are presented in Table 2.

\subsection{Non-Pharmacology Management}

Non-pharmacology management is an essential adjuvant to pharmacology treatment in patients suffering from cancer pain. Most of the patients will experience cancer pain because of tissue damage and stimulation of nerves by inflammatory mediators produced by tumours, side effects of surgery or radiotherapy, and musculoskeletal pain from inactivity. 
Table 2: Efficacy and Safety of the Newer Drugs in HER2-Negative Breast Cancer Treatment

\begin{tabular}{|c|c|c|c|c|}
\hline $\begin{array}{l}\text { Newer drugs } \\
\text { for breast } \\
\text { cancer } \\
\text { treatment }\end{array}$ & $\begin{array}{c}\text { Author } \\
\text { name(s), } \\
\text { year, } \\
\text { reference } \\
\text { number }\end{array}$ & $\begin{array}{c}\text { Study aim and objectives, } \\
\text { population involved in this } \\
\text { study }\end{array}$ & Efficacy & Safety \\
\hline Olaparib & $\begin{array}{c}\text { Mark } \\
\text { Robson, et } \\
\text { al. (2017) } \\
{[77] .}\end{array}$ & $\begin{array}{l}\text { It is a randomised, phase } 3 \\
\text { and open-label trial comparing } \\
\text { the monotherapy of olaparib } \\
\text { with standard therapies that } \\
\text { consist of capecitabine, } \\
\text { eribulin, or vinorelbine in } \\
\text { germline BRCA mutation and } \\
\text { HER2-negative metastatic } \\
\text { breast cancer patients. }\end{array}$ & $\begin{array}{l}\text { Patients with Olaparib monotherapy } \\
\text { have median progression-free } \\
\text { survival of } 2.8 \text { months longer and } \\
\text { has } 42 \% \text { lower risk of death or } \\
\text { disease progression when } \\
\text { compared to standard therapy ( } 95 \% \\
\text { Cl, } 0.43 \text { to } 0.80 ; P<0.001) \text {. }\end{array}$ & $\begin{array}{c}\text { Patients in the Olaparib group experienced } \\
\text { more often side effects of nausea, headache, } \\
\text { fatigue, vomiting, anaemia, and cough. } \\
\text { However, patients in the standard therapy } \\
\text { group were observed to experience more } \\
\text { frequent palmar-plantar erythrodysesthesia, } \\
\text { neutropenia, and elevated liver function } \\
\text { enzyme. }\end{array}$ \\
\hline \multirow[t]{2}{*}{ Talazoparib } & $\begin{array}{l}\text { Litton JK, } \\
\text { et al. } \\
\text { (2018) [79]. }\end{array}$ & $\begin{array}{l}\text { The trial displayed the } \\
\text { comparison between } \\
\text { talazoparib with standard } \\
\text { single-agent therapy } \\
\text { (capecitabine, gemcitabine, } \\
\text { vinorelbine or eribulin) in } \\
\text { advanced breast cancer and } \\
\text { BRCA1/2 germline mutation } \\
\text { patients. }\end{array}$ & $\begin{array}{l}\text { The outcome measure, progression- } \\
\text { free survival was significantly } \\
\text { extended in talazoparib group with } \\
8.6 \text { months as compared to } \\
\text { standard therapy group, } 5.6 \text { months. } \\
\text { The risk of disease progression or } \\
\text { death was } 46 \% \text { lower }(95 \% \mathrm{Cl}, 0.41 \\
\text { to } 0.71 ; \mathrm{P}<0.001) \text { in talazoparib } \\
\text { group as compared to standard } \\
\text { therapy. }\end{array}$ & $\begin{array}{l}\text { Common adverse events included fatigue } \\
(62 \%) \text {, anaemia }(53 \%) \text {, nausea }(49 \%), \\
\text { neutropenia }(35 \%) \text {, headache }(33 \%), \\
\text { thrombocytopenia }(27 \%) \text {, alopecia }(25 \%) \text {, } \\
\text { vomiting }(25 \%) \text {, diarrhoea }(22 \%) \text { and } \\
\text { suppressed appetite }(21 \%)[75] .\end{array}$ \\
\hline & $\begin{array}{l}\text { Nicholas } \\
\text { CT, et al. } \\
(2018)[81] \text {. }\end{array}$ & $\begin{array}{l}\text { The study aimed to evaluate } \\
\text { the talazoparib activity in } \\
\text { patients with advanced breast } \\
\text { cancer }(\mathrm{aBC}) \text { and germline } \\
\text { BRCA } 1 / 2 \text { mutation after } \\
\text { platinum or cytotoxic non- } \\
\text { platinum therapy. }\end{array}$ & $\begin{array}{l}\text { The primary efficacy endpoint, } \\
\text { objective response rate (ORR) in } \\
\text { patients with prior platinum therapy } \\
\text { (cohort } 1 \text { ) was } 21 \% \text { and } 37 \% \text { in } \\
\text { platinum-free cytotoxic regimens } \\
\text { (cohort } 2 \text { ). Median progression-free } \\
\text { survival was } 4.0 \text { months in cohort } 1 \\
\text { and } 5.6 \text { months in cohort } 2 \text { shown } \\
\text { that platinum-free regimen has a } \\
\text { higher efficacy with talazoparib. }\end{array}$ & $\begin{array}{l}\text { The major all-grade adverse events of } \\
\text { talazoparib included fatigue }(60 \%) \text {, anaemia } \\
(50 \%) \text {, thrombocytopenia }(48 \%) \text {, nausea } \\
(42 \%) \text { and diarrhoea }(35 \%) \text { in patient with } \\
\text { prior platinum therapy meanwhile anaemia } \\
(57 \%) \text {, neutropenia }(46 \%) \text {, nausea ( } 43 \%) \\
\text { and thrombocytopenia }(34 \%) \text { in patients with } \\
\text { prior platinum-free regimen. }\end{array}$ \\
\hline \multirow[t]{2}{*}{ Ribociclib } & $\begin{array}{l}\text { Tripathy D, } \\
\text { et al. } \\
\text { (2017) [82]. }\end{array}$ & $\begin{array}{l}\text { The study investigates the } \\
\text { difference of the progression- } \\
\text { free survival rate between } \\
\text { ribociclib and placebo in HR+ } \\
\text { advanced breast cancer } \\
\text { patients. The population } \\
\text { involved were } 668 \text { subjects } \\
\text { with HR+ advanced breast } \\
\text { cancer. }\end{array}$ & $\begin{array}{l}\text { Patients were randomised to be } \\
\text { given combination of ribociclib and } \\
\text { letrozole or combination of placebo } \\
\text { and letrozole. In first-line setting, } \\
\text { patient with ribociclib showed } \\
\text { significant increased progression- } \\
\text { free survival rate (PFS) compared to } \\
\text { placebo, with hazard ratio=0.56. } \\
\text { After } 12 \text { months, the PFS rate in } \\
\text { patient treated with ribociclib was } \\
72.8 \% \text { compared to } 60.9 \% \text { in patient } \\
\text { treated with placebo. }\end{array}$ & 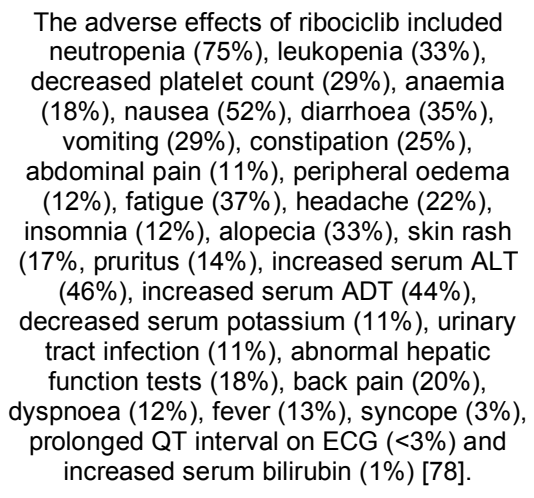 \\
\hline & $\begin{array}{l}\text { Dennis JS, } \\
\text { et al. } \\
\text { (2018) [84]. }\end{array}$ & $\begin{array}{l}\text { The study evaluates the effect } \\
\text { and progression-free survival } \\
\text { of ribociclib in combination } \\
\text { with fulvestrant compared to } \\
\text { placebo plus fulvestrant. } \\
\text { Under randomisation, } 484 \\
\text { postmenopausal women } \\
\text { received combination of } \\
\text { ribociclib and fulvestrant, } 242 \\
\text { were given combination of } \\
\text { placebo and fulvestrant. }\end{array}$ & $\begin{array}{l}\text { The median progression-free } \\
\text { survival was } 20.5 \text { months in subject } \\
\text { treated with combination of ribociclib } \\
\text { and fulvestrant compared to } 12.8 \\
\text { months in subjects treated with } \\
\text { combination of placebo and } \\
\text { fulvestrant with hazard ratio of } \\
0.577 \text {. }\end{array}$ & \\
\hline
\end{tabular}

Rehabilitative treatment or application of heat or cold therapy is recommended to reduce postoperative cancer pain $[83,84]$. In addition, to strengthen patient's motion ability and to reduce muscle tension, 
therapeutic exercise and massaging are the good options. Exercise will enhance patient's immunity as well as better control of mood as negative mood will intensify the pain $[85,86]$. Besides, patients can undergo cognitive behaviour therapy, which is a psychotherapeutic treatment that aimed to change the patient's emotion by changing their thoughts and behaviours [87] and to alleviate cancer pain. Hence, by tracking and changing the emotions and behaviours which intensified the cancer pain, it can improve patient's control over pain and thereby reduces the exacerbation of cancer pain [86]. As fatigue, depression, nausea, vomiting, hot flushes and anorexia are the side effects from breast cancer treatment, acupuncture may be useful in alleviate these side effects [85]. Research explained that acupuncture works by stimulating nerves and releasing endorphins in nervous system, thus relieve pain. It also stimulates the release of serotonin which give patients a feeling of well-being and reduce the symptoms associated with cancer therapy [86].

\section{CONCLUSION}

The treatment for HER2-negative breast cancer has various approach as the treatment depends on the severity and types of the breast cancer. Upon comparing the safety and efficacy of all new drugs that approved by US-FDA, the Talazoparib was considered as effective in HER2-negative breast cancer to increase the PFS rate, and Olaparib was considered as safe as it has fewer side effects compared to other drugs that approved in the same period. The combination of pharmacological and nonpharmacological treatments is both essential and works as partner in managing breast cancer in order to improve the prognosis of the patient and their quality of life.

\section{FUNDING}

This research received no external funding.

\section{CONFLICTS OF INTEREST}

The authors declare no conflict of interest.

\section{AUTHOR CONTRIBUTIONS}

Palanisamy Sivanandy conceived and designed the study and wrote the paper; Suresh Shanmugam, Rui Ying Lau, Jonathan Yvong Syen Chin, Xiao Xiang Lee carried out the data collection procedures; Yun Yun Lau, Wai Ching Lee, Iqbal Danial Said, Jing Ying Lee,
Karthikayini Krishnasamy carried out initial draft preparation and analysis of the data.

\section{REFERENCES}

[1] Breast Cancer. Breast Cancer Symptoms. MedlinePlus. Available online: https://medlineplus.gov/breastcancer.html (accessed June 16, 2019).

[2] Ferri FF. Ferri's Clinical Advisor 2019. 1st ed. Elsevier Health Sciences 2019.

[3] Hartmann LC, Sellers TA, Frost MH, Lingle WL, Dengnim $\mathrm{AC}$, et al. Benign breast disease and the risk of breast cancer. Obstet Gynecol 2016; 71(8): 472-473. https://doi.org/10.1097/01.ogx.0000489578.68399.d7

[4] Malaysia Population Cancer Fact Sheet. The Global Cancer Observatory 2018. Available online: http://gco.iarc.fr/today/ data/factsheets/populations/458-malaysia-fact-sheets.pdf (accessed May 16, 2019).

[5] Freddie B, Jacques F, Isabelle S, Rebecca LS, Lindsey AT, Ahmedin J. Global cancer statistics 2018: GLOBOCAN estimates of incidence and mortality worldwide for 36 cancers in 185 countries. CA Cancer J Clin 2018; 68(6): 394-424. https://doi.org/10.3322/caac.21492

[6] Sat Dharam Kaur ND. Global breast cancer incidence 2018. Available online: http://mammalive.net/research/globalbreast-cancer-incidence-2018/ (accessed June 7, 2019).

[7] Nounou MI, ElAmrawy F, Ahmed N, Abdelraouf K, Goda S, Syed-Sha-Qhattal $\mathrm{H}$. Breast cancer: conventional diagnosis and treatment modalities and recent patents and technologies. Breast cancer (Auckl) 2015; 9: BCBCR-S29420. https://doi.org/10.4137/BCBCR.S29420

[8] Aydiner A, Igci A, Soran A. Breast cancer: a guide to clinical practice. Springer. 2018. https://doi.org/10.1007/978-3-319-96947-3

[9] Breast cancer information and support. Available online: https://www.breastcancer.org/ (accessed on May 13, 2019).

[10] Belinda Y, Nicholas CT, Alison J. An update on the medical management of breast cancer. BMJ 2014; $348: g 3608$. https://doi.org/10.1136/bmj.g3608

[11] Breast cancer in females. Available online: https://www.clinicalkey.com/\#!/content/clinical_overview/67s2.0-866e 25c5-15bf-4016-9ae0-fccae1a3e9e $\overline{5}$ (accessed June 16, 2019).

[12] Lynn CH, Thomas AS, Marlene HF, Wilma LL, Amy CD, Karthik $G$, et al. Benign breast disease and the risk of breast cancer. N Engl J Med 2005; 353(3): 229-237. https://doi.org/10.1056/NEJMoa044383

[13] Melissa CS, Jerry RB. Breast cancer causes, symptoms, types, treatment \& stages. Available online: https://www.emedicinehealth.com/breast_cancer/article_em. htm\#what_are_breast_cancer_causes_and_risk_factors (accessed June 17, 2019).

[14] King MC, Marks JH, Mandell JB. Breast and ovarian cancer risks due to inherited mutations in BRCA1 and BRCA2. Science 2003; 302(5645): 643-646. https://doi.org/10.1126/science.1088759

[15] Antoniou A, Pharoah, PD, Narod S, Risch HA, Eyfjord JE, Hopper JL, et al. Average risks of breast and ovarian cancer associated with BRCA1 or BRCA2 mutations detected in case series unselected for family history: a combined analysis of 22 studies. Am J Hum Genet 2003; 72(5): 11171130.

https://doi.org/10.1086/375033

[16] Ford D, Easton DF, Stratton M, Narod S, Goldgar D, Devilee $\mathrm{P}$, et al. Genetic heterogeneity and penetrance analysis of the BRCA1 and BRCA2 genes in breast cancer families. Am J Hum Genet 1998; 62(3): 676-689. PMID: 9497246. https://doi.org/10.1086/301749 
[17] Hsieh CC, Trichopoulos D, Katsouyanni K, Yuasa S. Age at menarche, age at menopause, height and obesity as risk factors for breast cancer: associations and interactions in an international case-control study. Int J Cancer 1990; 46(5): 796-800. PMID: 2228308. https://doi.org/10.1002/ijc.2910460508

[18] Rosner B, Colditz GA, Willett WC. Reproductive risk factors in a prospective study of breast cancer: the nurses' health study. Am J Epidemiol 1994; 139(8): 819-835. PMID: 8178795.

https://doi.org/10.1093/oxfordjournals.aje.a117079

[19] Sieri S, Krogh V, Bolelli G, Abagnato CA, Grioni S, Pala V, et al. Sex hormone levels, breast cancer risk, and cancer receptor status in postmenopausal women: the ORDET cohort. Cancer Epidemiol Biomarkers Prev 2009; 18(1): 169176. https://doi.org/10.1158/1055-9965.EPI-08-0808

[20] Sharma GN, Dave R, Sanadya J, Sharma P, Sharma KK. Various types and management of breast cancer: an overview. J Adv Pharm Technol Res 2010; 1(2): 109-26. PMID: 22247839.

[21] Anderson GL, Manson J, Wallace R, Lund B, Hall D, Davis S, et al. Implementation of the women's health initiative study design. Ann Epidemiol 2003; 13(9): S5-S17. https://doi.org/10.1016/S1047-2797(03)00043-7

[22] Colditz GA, Rosner B. Cumulative risk of breast cancer to age 70 years according to risk factor status: data from the nurses' health study. Am J Epidemiol 2000; 152(10): 950964.

https://doi.org/10.1093/aje/152.10.950

[23] Shah R, Rosso K, Nathanson SD. Pathogenesis, prevention, diagnosis and treatment of breast cancer. World $\mathrm{J}$ Clin Oncol 2014; 5(3): 283.

https://doi.org/10.5306/wjco.v5.i3.283

[24] Lahmann PH, Hoffmann K, Allen N, Van-Gils CH, Khaw KT, Tehard $\mathrm{B}$, et al. Body size and breast cancer risk: findings from the European prospective investigation into cancer and nutrition (EPIC). Int J Cancer 2004; 111(5): 762-771. https://doi.org/10.1002/ijc.20315

[25] Chlebowski RT. Nutrition and physical activity influence on breast cancer incidence and outcome. Breast 2013; 22(2): S30-S37.

https://doi.org/10.1016/j.breast.2013.07.006

[26] Chen WY, Rosner B, Hankinson SE, Colditz GA, Willett WC. Moderate alcohol consumption during adult life, drinking patterns, and breast cancer risk. JAMA 2011; 306(17): 18841890. https://doi.org/10.1001/jama.2011.1590

[27] Ballard T, Lagorio S, De Angelis G, Verdecchia A. Cancer incidence and mortality among flight personnel: a metaanalysis. Aviat Space Environ Med 2000; 71(3): 216-24. PMID: 10716165.

[28] Pukkala E, Kesminiene A, Poliakov S, Ryzho A, Drozdovitch $\mathrm{V}$, Kovgan L, et al. Breast cancer in Belarus and Ukraine after the Chernobyl accident. Int J Cancer 2006; 119(3): 651658.

https://doi.org/10.1002/ijc.21885

[29] Germain D. Estrogen carcinogenesis in breast cancer. Endocrinol Metab Clin North Am 2011; 40(3): 473-84. https://doi.org/10.1016/j.ecl.2011.05.009

[30] Winchester DJ, Winchester DP, Hudis CA, Norton L. Breast Cancer, 2nd ed. BC Decker: PMPH-USA 2006.

[31] Wang C, Bai F, Zhang LH, Scott A, Li E, Pei XH. Estrogen promotes estrogen receptor negative BRCA1-deficient tumor initiation and progression. Breast Cancer Res 2018; 20(1): 74. https://doi.org/10.1186/s13058-018-0996-9

[32] Bowcock AM. Breast cancer: molecular genetics, pathogenesis, and therapeutics. Springer Science \& Business Media 1999.
[33] Russo J, Russo $\mathrm{IH}$. The role of estrogen in the initiation of breast cancer. J Steroid Biochem Mol Biol 2006; 102(1-5): 89-96. https://doi.org/10.1016/j.jsbmb.2006.09.004

[34] Yue W, Wang JP, Li Y, Fan P, Liu G, Zhang N, et al. Effects of estrogen on breast cancer development: Role of estrogen receptor independent mechanisms. Int J Cancer 2010; 127(8): 1748-1757. https://doi.org/10.1002/ijc.25207

[35] McPhee SJ, Hammer G, Kwok Y. Pathophysiology of disease. 8th ed. McGraw-Hill Education LLC: New York USA 2019.

[36] Jin W, Wu L, Liang K, Liu B, Lu Y, Fan Z. Roles of the PI-3K and MEK pathways in Ras-mediated chemoresistance in breast cancer cells. Br J Cancer 2003; 89(1): 185. https://doi.org/10.1038/sj.bjc.6601048

[37] Dickson RB, Stancel GM. Estrogen receptor-mediated processes in normal and cancer cells. J Natl Cancer Inst Monogr 2000; 27: 135-145. PMID: 10963625.

https://doi.org/10.1093/oxfordjournals.jncimonographs.a0242 $\underline{37}$

[38] Pietras RJ, Marquez-Garban DC. Membrane-associated estrogen receptor signaling pathways in human cancers. Clin Cancer Res 2007; 13(16): 4672-4676.

https://doi.org/10.1158/1078-0432.CCR-07-1373

[39] Taib NA, Yip CH, Low WY. Recognising symptoms of breast cancer as a reason for delayed presentation in Asian womenthe psycho-socio-cultural model for breast symptom appraisal: opportunities for intervention. Asian Pac J Cancer Prev 2011; 12(6): 1601-8. PMID: 22126506.

[40] Singh D, Miettinen J, Duffy S, Malila N, Pitkaniemi J, Anttila A. Association of symptoms and interval breast cancers in the mammography-screening programme: population-based matched cohort study. Br J Cancer 2018; 119(11): 1428. https://doi.org/10.1038/s41416-018-0308-2

[41] Papadakis MA, McPhee SJ, Bernstein J. Quick Medical Diagnosis and Treatment. McGraw-Hill: New York USA 2019.

[42] Breast cancer. Centers for Disease Control and Prevention. Available online: http://www.cdc.gov/obesity/downloads/ PA_2011_WEB.pdf (accessed June 20, 2019).

[43] Harris JR, Lippman ME, Morrow M, Osborne CK. Diseases of the Breast. 5th ed. Wolters Kluwer Health: Philadelphia USA 2014.

[44] Usatine RP, Smith MA, Chumley HS, Mayeaux EJ. The Color Atlas of Family Medicine. 2nd ed. McGraw-Hill: New York USA 2013.

[45] Wahl RL, Imaging. In: Niederhuber JE, Armitage JO, Doroshow JH, Kastan MB, Tepper JE. Abeloff's Clinical Oncology. 4th ed. Churchill Livingstone 2014; 18: pp. 242246.

[46] Hayes DF, Lippman ME. Breast Cancer. In: Jameson J, Fauci AS, Kasper DL, Hauser SL, Longo DL, Loscalzo J. Harrison's Principles of Internal Medicine. 20th ed. McGrawHill: New York 2018.

[47] Fernando J, Jones R. The principles of cancer treatment by chemotherapy. Surg Oxf 2015; 33(3): 131-135. https://doi.org/10.1016/j.mpsur.2015.01.005

[48] American Cancer Society. Information and resources about for cancer: breast, colon, lung, prostate, skin. Available online: https://www.cancer.org/ (accessed June 13, 2019).

[49] MacNeill F, Karakatsanis A. Over surgery in breast cancer. Breast 2017; 31: 284-289. https://doi.org/10.1016/j.breast.2016.10.023

[50] National Breast Cancer Foundation. Available online: https://www.nationalbreastcancer.org/ (accessed May 13, 2019).

[51] Scholar E. Antimetabolites. xPharm: The comprehensive pharmacology reference 2007: 1-4. https://doi.org/10.1016/j.biopha.2018.02.108 
[52] Wu Y, Zhang D, Wu B, Quan Y, Liu D, Li Y, et al. Synergistic activity of an antimetabolite drug and tyrosine kinase inhibitors against breast cancer cells. Chem Pharm Bull 2017; 65(8): 768-775.

https://doi.org/10.1248/cpb.c17-00261

[53] Methotrexate. BC cancer agency cancer drug manual [Monograph on the internet]. BC Cancer Agency Cancer Drug Manual; 2017 [cited 2019 May 13]: 1-16. Available online: http://www.bccancer.bc.ca/drug-databasesite/Drug\%20Index/Methotrexate_monograph.pdf

[54] Abotaleb M, Kubatka P, Caprnda M, Varghese E, Zolakova $\mathrm{B}$, Zubor $\mathrm{P}$, et al. Chemotherapeutic agents for the treatment of metastatic breast cancer: an update. Biomed Pharmacother 2018; 101: 458-477. https://doi.org/10.1016/j.biopha.2018.02.108

[55] Inoue K, Yuasa H. Molecular basis for pharmacokinetics and pharmacodynamics of methotrexate in rheumatoid arthritis therapy. Drug Metab Pharmacokinet 2014; 29(1): 12-19. PMID: 24284432. https://doi.org/10.2133/dmpk.DMPK-13-RV-119

[56] Avendano C, Menendez JC. Antimetabolites. Med Chem Anticancer Drugs 2008; 9: 52. https://doi.org/10.1016/B978-0-444-52824-7.00002-0

[57] Stanton RA, Gernert KM, Nettles JH, Aneja R. Drugs that target dynamic microtubules: a new molecular perspective. Med Res Rev 2011; 31(3): 443-481.

https://doi.org/10.1002/med.20242

[58] Hevener K, Verstak TA, Lutat KE, Riggsbee DL, Mooney JW. Recent developments in topoisomerase-targeted cancer chemotherapy. Acta Pharm Sin B 2018; 8(6): 844-861. https://doi.org/10.1016/j.apsb.2018.07.008

[59] Bush NG, Evans-Roberts K, Maxwell A. DNA topoisomerases. EcoSal Plus 2015; 6(2): 67-81. https://doi.org/10.1128/ecosalplus.ESP-0010-2014

[60] Kathiravan MK, Kale AN, Nilewar S. Discovery and development of topoisomerase inhibitors as anticancer agents. Mini Rev Med Chem 2016; 16(15): 1219-1229. PMID: 27549098.

https://doi.org/10.2174/1389557516666160822110819

[61] Damiani RM, Moura DJ, Viau CM, Brito V, Moras AM, Henriques JAP, et al. Influence of PARP-1 inhibition in the cardiotoxicity of the topoisomerase 2 inhibitors doxorubicin and mitoxantrone. Toxicol In vitro 2018; 52: 203-213.

https://doi.org/10.1016/j.tiv.2018.06.013

[62] Scholar E. Alkylating agents. xPharm: The comprehensive pharmacology reference 2007: 1-4. https://doi.org/10.1016/B978-008055232-3.61034-7

[63] Charlene AM. Carcinogenic alkylating agents. In: La DK, Upton PB, Swenberg JA. Comprehensive Toxicology. 2nd ed. Science Direct 2010; pp. 63-83.

https://doi.org/10.1016/B978-0-08-046884-6.01405-6

[64] Peter NB, Morris JB, Pankaj S. Neoplastic disease and immunosuppression. In: Wasan H. Clinical Pharmacology. 11th ed. Churchill Livingstone 2012; pp. 509-525. https://doi.org/10.1016/B978-0-7020-4084-9.00070-7

[65] Frank JD, Barton SJ, Angelo JM. Antineoplastic Drugs. In: Kwok KK, Vincent EC, Gibson JN. Pharmacology and therapeutics for dentistry. 7th ed. Mosby 2017; pp. 530-562. https://doi.org/10.1016/B978-0-323-39307-2.00036-9

[66] Egger SJ, Willson ML, Morgan J, Walker HS, Carrick S, Ghersi $D$, et al. Platinum-containing regimens for metastatic breast cancer. Cochrane Database Syst Rev 2017; 6: CD003374.

https://doi.org/10.1002/14651858.CD003374.pub4

[67] Zhao $\mathrm{H}$, Yang Q, Hu Y, Zhang J. Antitumor effects and mechanisms of olaparib in combination with carboplatin and BKM120 on human triple negative breast cancer cells. Oncol Rep 2018; 40(6): 3223-3234.

https://doi.org/10.3892/or.2018.6716
[68] O'sullivan CC, Loprinzi CL, Haddad TC. Updates in the evaluation and management of breast cancer. Mayo Clin Proc 2018; 93(6): 794-807. https://doi.org/10.1016/j.mayocp.2018.03.025

[69] Becourt S, Espie M. Hormonal treatment of breast cancer. In: Encyclopedia of Endocrine Diseases. 2019; pp. 646-655. https://doi.org/10.1016/B978-0-12-801238-3.64351-9

[70] Hormone therapy for breast cancer. Available online: https://www.cancer.gov/types/breast/breast-hormonetherapy-fact-sheet (accessed July 20, 2019).

[71] Hormone therapy for breast cancer. American Cancer Society. Available online: https://www.cancer.org/cancer/ breast-cancer/treatment/hormone-therapy-for-breastcancer.html (accessed July 20, 2019).

[72] Draganescu M, Carmocan C. Hormone therapy in breast cancer. Chirurgia (Bucur) 2017; 112(4): 413-417. https://doi.org/10.21614/chirurgia.112.4.413

[73] Godone RLN, Leitao GM, Araujo NB, Castelletti CHM, LimaFilho JL, Martins DBG. Clinical and molecular aspects of breast cancer: Targets and therapies. Biomed Pharmacother 2018; 106: 14-34. https://doi.org/10.1016/j.biopha.2018.06.066

[74] Ju J, Zhu AJ, Yuan P. Progress in targeted therapy for breast cancer. Chronic Dis Transl Med 2018; 4(3): 164-175. https://doi.org/10.1016/j.cdtm.2018.04.002

[75] FDA approves olaparib for germline BRCA-mutated metastatic breast cancer. Available online: https://www.fda.gov/Drugs/InformationOnDrugs/ApprovedDru gs/ucm592357.htm (accessed July 21, 2019).

[76] Dziadkowiec KN, Gąsiorowska E, Nowak-Markwitz E, Jankowska A. PARP inhibitors: review of mechanisms of action and BRCA1/2 mutation targeting. Prz Menopauzalny 2016; 15(4): 215-219. https://doi.org/10.5114/pm.2016.65667

[77] Robson M, Im SA, Senkus E, Xu B, Domchek SM, Masuda $\mathrm{N}$, et al. Olaparib for metastatic breast cancer in patients with a germline BRCA mutation. N Eng J Med 2017; 377(6): 523533. https://doi.org/10.1056/NEJMoa1706450

[78] US Food and Drug Administration. FDA approves talazoparib for gBRCAm HER2-negative locally advanced or metastatic breast cancer. Available online: https://www.fda.gov/Drugs/ InformationOnDrugs/ApprovedDrugs/ucm623540.htm (accessed July 25, 2019].

[79] Litton JK, Rugo HS, Ettl J, Hurvitz SA, Goncalves A, Lee KH, et al. Talazoparib in patients with advanced breast cancer and a germline BRCA mutation. N Eng J Med 2018: 379(8): 753-763.

https://doi.org/10.1056/NEJMoa1802905

[80] Talzenna (talazoparib). Available online: https://www.accessdata.fda.gov/drugsatfda_docs/label/2018/ 211651s000lbl.pdf (accessed July 20, 2019).

[81] Turner NC, Telli ML, Rugo HS, Mailliez A, Ettl J, Grischke EM, et al. A phase II study of Talazoparib after platinum or cytotoxic nonplatinum regimens in patients with advanced breast cancer and germline BRCA1/2 mutations (ABRAZO). Clin Cancer Res 2019; 25(9): 2717-2724. https://doi.org/10.1158/1078-0432.CCR-18-1891

[82] Tripathy D, Bardia A, Sellers WR. Ribociclib (LEE011): mechanism of action and clinical impact of this selective cyclin-dependent kinase $4 / 6$ inhibitor in various solid tumors. Clin Cancer Res 2017; 23(13): 3251-3262. https://doi.org/10.1158/1078-0432.CCR-16-3157

[83] O'Shaughnessy J, Petrakova K, Sonke GS, Conte P, Arteaga $\mathrm{CL}$, Cameron DA, et al. Ribociclib plus letrozole versus letrozole alone in patients with de novo HR+, HER2advanced breast cancer in the randomized MONALEESA-2 trial. Breast Cancer Res Treat 2018; 168: 127-134. https://doi.org/10.1007/s10549-017-4518-8 
[84] Slamon DJ, Neven P, Chia S, Fasching PA, De Laurentiis M, Im SA, et al. Phase III randomized study of Ribociclib and Fulvestrant in hormone receptor-positive, human epidermal growth factor receptor 2-negative advanced breast cancer: MONALEESA-3. J Clin Oncol 2018; 36(24): 2465-2472. https://doi.org/10.1200/JCO.2018.78.9909

[85] Breast cancer care and prevention: non-pharmacological intervention. University of Wisconsin integrative medicine. Available online: https://www.fammed.wisc.edu/files/webfm- uploads/documents/outreach/im/module_breast_ca_clinician. pdf (accessed July 20, 2019).

[86] Pujol LA, Monti DA. Managing cancer pain with nonpharmacologic and complementary therapies. J Am Osteopath Assoc 2007; 107: ES15-ES21. PMID: 18165373.

[87] Daniels S. Cognitive behavior therapy for patients with cancer. J Adv Pract Oncol 2015; 6: 54-6. PMID: 26413374. https://doi.org/10.6004/jadpro.2015.6.1.5 